\title{
Tax Regulation, Transportation Innovation, and the Sharing Economy
}

\author{
Jordan M. Barry† \& Paul L. Caron $\dagger$
}

\section{INTRODUCTION}

Recent years have seen the emergence of a number of businesses that enable consumers to share assets in new ways. Some have predicted that this "sharing economy" will change the world; ${ }^{1}$ others are skeptical. ${ }^{2}$ Whatever the future holds, the sharing economy has already experienced tremendous growth and attracted considerable investment capital and talent. ${ }^{3}$

The sharing economy is a prominent example of an innovative way of doing business that has been made possible by new technology. Unfortunately, existing regulatory structures often discourage such innovations, reducing their popularity and slowing their development. This Essay explores this dynamic in the context of the transportation sector of the sharing economy and the qualified transportation-fringe-benefit rules of Internal Revenue Code $\$ 132 .{ }^{4}$

$\dagger$ Professor of Law, University of San Diego School of Law.

t† Professor of Law, Pepperdine University School of Law.

We thank Michael B. Dorff, Victor Fleischer, Michael D. Guttentag, Emily Keifer, Yoon-Ho Alex Lee, David Min, and Elizabeth Pollman for their helpful and insightful comments.

1 See, for example, Bryan Walsh, 10 Ideas That Will Change the World: Today's Smart Choice: Don't Own. Share (Time Mar 17, 2011), online at http://content time .com/time/specials/packages/article/0,28804,2059521_2059717_2059710,00.html (visited Feb 23, 2015). See also The Rise of the Sharing Economy (Economist Mar 9, 2013), online at http://www.economist.com/news/leaders/21573104-internet-everything-hire-rise-sharingeconomy (visited Feb 23, 2015); Natasha Singer, In the Sharing Economy, Workers Find Both Freedom and Uncertainty (NY Times Aug 16, 2014), online at http://www.nytimes .com/2014/08/17/technology/in-the-sharing-economy-workers-find-both-freedom-anduncertainty.html?_r=0 (visited Feb 23, 2015).

2 See, for example, Joe Mathews, The Sharing Economy Boom Is About to Bust (Time June 27, 2014), online at http://time.com/2924778/airbnb-uber-sharing-economy (visited Feb 23, 2015).

3 See Tomio Geron, Lyft Raises $\$ 60$ Million as Ride Sharing Competition Heats Up (Forbes May 23, 2013), online at http://www.forbes.com/sites/tomiogeron/2013/05/23/lyftraises-60-million-as-ride-sharing-competition-heats-up (visited Feb 23, 2015).

426 USC $\$ 132$ (1986). All references to a section are to the Internal Revenue Code of 1986 unless otherwise specified. 
This Essay proceeds as follows. Part I provides background on the transportation sharing economy. Part II examines the problem that regulators confront, particularly with respect to emerging industries. Part III explores the impact of the $\S 132$ qualified transportation-fringe-benefit provisions on bicycle- and car-sharing services. Part IV briefly discusses two of the most common regulatory responses to the problems identified in this Essay.

\section{THE TRANSPORTATION SHARING ECONOMY}

Sharing assets is not a new idea. This is especially true in the context of transportation. ${ }^{5}$ Private and public masstransportation services, such as locomotives, ferries, buses, and commercial airlines, give consumers access to a portion of a vehicle for a particular period of time. Car- and bicycle-rental companies also fit within the sharing economy: they allow consumers to share access to an entire vehicle across time. What differentiates emerging sharing-economy businesses from these existing services is that the former use recently developed information technology to enable new kinds of sharing arrangements that, due to transaction costs, were previously too difficult to implement.

For example, consider a large group of college students who live on campus. Suppose that each has some need for a car but does not expect to use a car often enough to justify purchasing one. It might make sense for the students to share access to a single car, with several of them using it at different points during a given day. However, such an arrangement requires a lot of coordination. Who gets to use the car when? How does a user tell all the other users that she will be using the car at a particular time? Who pays for gas, maintenance, and insurance? In theory, this could all be resolved via appropriate contracting, ${ }^{6}$ but in practice, these logistical problems have prevented this type of sharing arrangement from becoming very common.

New information technology, primarily in the form of computing power and widespread access to the Internet through

\footnotetext{
5 Lodging is another large component of the sharing economy. Hotels, hostels, and campgrounds are similar to mass-transportation services in this respect. Condominiums, cooperatives, and apartments are longer-term arrangements with similar underlying principles. Time-shares also fit in with the sharing-economy concept.

6 For example, the students could form a partnership and spell out each student's rights and responsibilities in the partnership agreement.
} 
mobile devices, has made this type of sharing arrangement much more manageable. Many car-sharing services have websites - and, importantly, smartphone apps - that address these coordination issues. These websites and apps empower users to reserve cars and track their location and availability. They also allow car-sharing companies to identify and punish noncompliance, such as when a user keeps a car beyond the agreed-upon time. ${ }^{7}$

A second form of car sharing involves using similar information technology to facilitate transactions between vehicle owners and people who would like to use those vehicles for short periods of time. Under one version of this model, exemplified by Uber and Lyft, the owner of the vehicle picks up a user and takes her somewhere, much like a conventional taxi service. ${ }^{8}$ Another version of this model, exemplified by JustShareIt, allows vehicle owners to rent their cars to users without having to drive them, much like a conventional car-rental agency. ${ }^{9}$

Technological innovation has fostered bicycle-sharing programs in much the same way. Users can access bicycles from an automated, unmanned depot, where they pay by credit card. The bicycles are often equipped with GPS devices that make them easy to track. Bicycle-sharing systems usually feature many bicycle depots integrated into a single system. When a bicycle is returned to a depot, the user checks the bicycle back in and her credit card is charged accordingly. ${ }^{10}$

\section{REGULATORS AND EMERGING INDUSTRIES}

When parties transact, it is helpful to think of them as meeting over a bargaining table. They hash out the terms and structure of their deal, reach an agreement, and go from there. This negotiation - either literal or metaphorical, and mediated by the market - gives the parties a chance to structure the deal in a way that advances each party's interests as much as possible. ${ }^{11}$

\footnotetext{
7 See, for example, How It Works (Zipcar), online at http://www.zipcar.com/how (visited Feb 23, 2015).

8 See, for example, How Uber Works (Uber), online at http://support.uber.com/he/ en-us/sections/200390138 (visited Feb 23, 2015).

9 See How It Works (JustShareIt), online at http://www.justshareit.com/jsi/website/ howItWorks.do\# (visited Feb 23, 2015).

10 See, for example, How It Works (Divvy Bikes), online at https://www.divvybikes .com/how-it-works (visited Feb 23, 2015).

11 See generally Victor Fleischer, Regulatory Arbitrage, 89 Tex L Rev 227 (2010); Jordan M. Barry, On Regulatory Arbitrage, 89 Tex L Rev See Also 69 (2011).
} 
But often, deals have externalities - they affect other people besides the parties themselves. Those people are not at the negotiating table, so they cannot assert and protect their interests during the negotiations.

Real-world transactions provide many examples of this dynamic. ${ }^{12}$ But for our purposes, it behooves us to focus on one particular party that has an interest in most transactions but is rarely at the negotiating table: the US government. ${ }^{13}$ Depending on how the parties structure a transaction, the federal government stands to receive more or less tax revenue. ${ }^{14}$

Even when the US government does not have a seat at the negotiating table, it is not entirely without recourse. The government promulgates laws and regulations with which the parties must comply. In doing so, a conscientious tax authority must engage in a delicate balancing act. On the one hand, it must create rules that enable the government to collect the revenue that it needs. On the other hand, the taxing authority must treat all taxpayers equitably and avoid distorting the economy in inefficient ways-all the while minimizing the compliance burdens imposed on taxpayers.

The parties' interest is more straightforward: they want to pay the government as little as possible. Every dollar that the parties do not pay the government is a dollar that they can divide among themselves. This incentive-to look for ways to structure their transaction so as to pay the government less-is always there, and it drives many creative and cutting-edge transactions.

The government, of course, knows this well, and it crafts tax laws and regulations with an eye toward encouraging compliance and discouraging transaction structures designed to avoid taxes. For example, employers are required to report to the government how much they pay their individual employees in salary and must withhold and pay taxes on behalf of their employees. ${ }^{15}$ These reporting and withholding obligations largely foreclose any opportunity for employees to avoid paying taxes by

12 For example, a homeowner may hire a painter to paint her home a hideous color that bothers her neighbors.

13 The government will often have several interests in a transaction, but this Essay focuses primarily on the government's interest as a revenue collector. See Fleischer, 89 Tex L Rev at 238 (cited in note 11) ("[C]onceptually there are three parties, not two, at the negotiating table [in tax transactions]: the buyer, the seller, and the government.").

14 The same, of course, is true of state governments.

1526 USC \& 3402 
misreporting their salary income. ${ }^{16}$ There are also rules that prevent employees and employers from avoiding these obligations by declaring that employees are independent contractors. ${ }^{17}$

The government's job-crafting rules that encourage compliance, discourage avoidance, and do not impose a heavy compliance burden on taxpayers - is an extremely difficult one. On many occasions, a rule intended to constrain taxpayers' taxavoidance behavior ultimately opens up new opportunities for taxpayers to avoid paying taxes. ${ }^{18}$ Or, as Professor Marty Ginsburg colorfully stated, "every stick crafted to beat on the head of a taxpayer will metamorphose sooner or later into a large green snake and bite the commissioner on the hind part." 19

Given the incentives that the government and, more importantly, taxpayers face, the government's approach to crafting tax law is usually one of caution. Special dispensations and tax benefits should be crafted narrowly to minimize taxpayers' ability to utilize tax laws in unexpected and unintended ways. New transaction structures may be driven by the parties' goal of reducing their tax burdens and should be met with some skepticism. ${ }^{20}$ Even if new structures are not driven by a desire to avoid

16 See Bruce Bartlett, Tax Withholding Still Controversial after 70 Years, NY Times Blog (NY Times Oct 22, 2013), online at http://economix.blogs.nytimes.com/2013/10/22/ tax-withholding-still-controversial-after-70-years (visited Feb 23, 2015).

17 See Robert W. Wood, IRS Inspector Urges Crackdown on Mislabeling Independent Contractors' (Forbes July 30, 2013), online at http://www.forbes.com/sites/robertwood/ 2013/07/30/irs-inspector-urges-crackdown-on-mislabeling-independent-contractors (visited $\mathrm{Feb} 23,2015$ ) (describing the tax consequences of misidentifying workers as contractors).

18 See, for example, Martin D. Ginsburg, Making the Tax Law through the Judicial Process, 70 ABA J 74, 76 (Mar 1984) (describing taxpayer manipulation of the Supreme Court's ruling in the "Corn Products Refining Case," which was intended to restrain the ability of taxpayers to avoid taxes on capital gains).

19 Id.

20 For example, in the recent spate of corporate inversions-in which US corporations merged into businesses incorporated in foreign countries with lower corporate tax rates-corporations have disclaimed any motivation to reduce taxes while using a structure that in fact reduces taxes. See, for example, Julie Jargon, Burger King Defends Plan to Buy Tim Hortons; Company Says Global Expansion Ambitions, Not Tax Considerations, Fueling $\$ 11$ Billion Deal (Wall St J Aug 26, 2014), online at http://www.wsj .com/articles/burger-king-to-buy-tim-hortons-1409053466 (visited Feb 23, 2015); David Gelles, After Tax Inversion Rules Change, AbbVie and Shire Agree to Terminate Their Deal, Dealbook (NY Times Oct 20, 2014), online at http://dealbook.nytimes.com/2014/ 10/20/abbvie-and-shire-agree-to-terminate-their-deal (visited Feb 23, 2015) ("In announcing the termination of the deal, AbbVie lashed out at the Obama administration for changing the rules [on inversions]. . . This was a change in tune for AbbVie, which previously said that its deal for Shire was not motivated by tax considerations."). See also generally Americans for Tax Fairness, Whopper of a Tax Dodge: How Burger King's Inversion 
taxes, they may simply not fit well into an existing regulatory regime that was designed with a particular transaction template in mind.

This dynamic can pose problems for new industries. ${ }^{21}$ First, new-industry players often do not qualify for tax breaks targeted at related industries that are more established. Regulators often prefer that such provisions be written narrowly, to minimize gamesmanship and increase revenue collection. Moreover, established-industry players that push for the enactment of such benefits often do not want them to apply to upstarts who might disrupt their existing businesses.

Second, new industries often adopt new ways of doing business. The existing regulatory structure may not be well configured to respond. This may make regulators unfriendly or apathetic to new-industry issues. ${ }^{22}$ Even when new industries

Could Shortchange America, online at http://www.americansfortaxfairness.org/files/WhopperTax-Dodge.pdf (visited Feb 23, 2015).

21 There are, of course, exceptions. See, for example, Calvin H. Johnson, Capitalize Costs of Software Development, 124 Tax Notes 603, 607-09 (Aug 10, 2009) (noting that video game developers receive multiple tax breaks that are designed for separate entertainment and software businesses); David Kocieniewski, Rich Tax Breaks Bolster Makers of Video Games (NY Times Sept 10, 2011), online at http://www.nytimes.com/2011/09/11/ technology/rich-tax-breaks-bolster-video-game-makers.html?_r=2\&hp=\&pagewanted=all\& (visited Feb 23, 2015) (same).

22 We note that industries with new business models sometimes have incentives to push the regulatory envelope. In the early stages, a key challenge that new businesses must overcome is to convince the world that their model is viable. For example, Amazon.com intended to take advantage of economies of scale that would result from moving large quantities of merchandise through its distribution system. See Steve Wasserman, The Amazon Effect (The Nation June 18, 2012), online at http:/www.thenation.com/ article/168125/amazon-effect (visited Feb 23, 2015). To do this, it needed to attract both buyers and suppliers to its web site. One way to do this was by offering low prices. One way to lower its prices was by avoiding state sales taxes. Amazon.com initially took an aggressive approach on the sales-tax front. See Will Amazon Get a Visit from the Tax Man (Wall St J June 25, 2008), online at http:/www.wsj.com/articles/SB121433413465400637 (visited Feb 23, 2015). Over time, Amazon.com became more successful and the tax advantage became a much less important issue for it and a much more important issue for state and local governments; Amazon.com now collects state sales tax on most of its US sales. See Greg Bensinger, Which States Make You Pay an Amazon Sales Tax (Wall St J Oct 1, 2014), online at http://online.wsj.com/articles/states-that-make-amazon-pay-salestaxes-1412185657 (visited Feb 23, 2015).

Uber and Lyft have taken aggressive positions that have fueled contentious relationships with taxi commissions in many jurisdictions, though there are some signs that this may change. See Ravi Mahesh, Note, From Jitney Buses to App-Based Ridesharing: Understanding California's "Third Way" Approach to Ride-for-Hire Regulation, 88 So Cal L Rev *2-3 (forthcoming 2015), online at http://papers.ssrn.com/sol3/papers.cfm?abstract _id=2474452 (visited Feb 23, 2015); Douglas Macmillan and Lisa Fleisher, How SharpElbowed Uber Is Trying to Make Nice (Wall St J Jan 29, 2015), online at http://www.wsj.com/articles/hard-driving-uber-gives-compromise-a-try-1422588782 (vis- 
succeed in getting favorable provisions enacted, the uncertainty surrounding developing business models can be problematic: Regulators worry that new benefits will be abused. Accordingly, they are usually inclined to write new benefits narrowly - and established-industry groups competing with new businesses may work to reinforce that inclination. When new industries are still developing, it can be hard to predict the ways in which their business models will progress. If a new industry's business model develops in a different way than initially expected, narrowly crafted benefits may not track the new model well, rendering them less valuable. It can take years for governments to catch up and revise these provisions. ${ }^{23}$

As we discuss in Part III, some of these dynamics can be seen in the context of tax-free transportation fringe benefits.

\section{QUALIFIED TRANSPORTA'TION FRINGE BENEFITS AND THE SHARING ECONOMY}

Employees receive a salary from their employers; they may also receive other benefits-known as "fringe benefits" - by virtue of their employment. Salary payments are taxable to the employee. ${ }^{24}$ When fringe benefits are nontaxable, employers and employees have strong incentives to convert salary into fringe benefits. Because the government does not take a cut, in the form of taxes, the employer and employee are left with more money to split between themselves.

ited Feb 23, 2015). AirBnB long resisted paying hotel taxes but is now taking a softer approach. See Joshua Brustein, Why AirBnB Wants to Start Paying Hotel Taxes, Businessweek (Bloomberg Oct 3, 2013), online at http://www.businessweek.com/articles/201310-03/why-airbnb-wants-to-start-paying-hotel-taxes (visited Feb 23, 2015); Ben Trefny, AirBnB to Start Charging Hotel Taxes in a Handful of Cities, All Tech Considered (National Public Radio Apr 18, 2014), online at http://www.npr.org/blogs/alltechconsidered/ 2014/04/18/304564169/airbnb-to-start-charging-hotel-taxes-in-a-handful-of-cities (visited Feb 23, 2015).

23 See generally Christopher Koopman, Matthew Mitchell, and Adam Thierer, The Sharing Economy and Consumer Protection: The Case for Policy Change (George Mason University Mercatus Center Dec 2014), online at http://mercatus.org/sites/default/files/ Koopman-Sharing-Economy.pdf (visited Feb 23, 2015); Christopher T. Lutz, Legitimizing the Sharing Economy: Reconciling the Tension between State and Local Tax Policy Concerns and Innovation (Bloomberg BNA Dec 5, 2014), online at http://www.hmblaw .com/media/92077/bloomberg_law_perspectives_article_-_lutz_12.8.2014.pdf (visited Feb $23,2015)$

24 See 26 USC $\$ 61$. See also Employer and Employee Responsibilities-Employment Tax Enforcement (Internal Revenue Service Feb 12, 2014), online at http://www.irs.gov/ uac/Employer-and-Employee-Responsibilities---Employment-Tax-Enforcement (visited Feb $23,2015)$ 
For example, when an employee receives a salary payment from an employer, that payment is subject to federal income tax. However, suppose that if the employer instead gives the employee a bicycle, the employee does not have to pay income tax on it. Further, suppose that the federal income tax rate is 30 percent. If the employer pays an employee $\$ 1,000$, the employee will keep only $\$ 700$ after taxes. The employee and employer would both be better off if the employer bought a bicycle worth $\$ 900$ and gave that to the employee instead-the employer would keep $\$ 100$ more and, after taxes, the employee would have a bicycle worth $\$ 900$ instead of $\$ 700$ in cash. ${ }^{25}$

From a tax-policy perspective, this arrangement creates numerous problems. Suppose that the employee values the bicycle above $\$ 700$ but below $\$ 900$. Because of the tax advantage, the employee will still prefer to receive a bicycle instead of $\$ 1,000$ cash. This arrangement is inefficient-the employer is spending $\$ 900$ to create as little as $\$ 700$ in benefit for the employee. But even if the employee values the bicycle at its full $\$ 900$ cost, this arrangement remains problematic. The government needs revenue, and the use of bicycle purchases as side payments will reduce the tax base. Consequently, the government will have to raise tax rates on other types of income in order to make up the difference. Higher tax rates cause more distortions of economic activity and make tax-avoidance transactions-like bicycle side payments to employees-more attractive. ${ }^{26}$ This necessitates more rate raising, which feeds back into the cycle.

In general, fringe benefits are included in taxable income, ${ }^{27}$ which avoids the types of problems described above. There are some notable exceptions, however. ${ }^{28}$ Section 132, entitled "Certain Fringe Benefits," provides a special rule that exempts certain fringe benefits from the general rule, rendering those fringe benefits nontaxable. ${ }^{29}$

25 For simplicity, we ignore the tax treatment of the employer as well as the employment tax consequences to the employer and employee.

26 There also may be equity concerns, as some taxpayers may be in a position to benefit from the bicycle-payment tax advantage while others are not.

27 See 26 USC $\$ 61(a)(1)$.

28 See, for example, 26 USC $\$ 106$ (exempting employer-provided health insurance)

2926 USC \$ 132(a) (listing categories excluded from gross income and thereby exempted from income tax). 
One of these specially exempted benefits is a "qualified transportation fringe." 30 Qualified transportation fringes are certain types of benefits that employers provide to facilitate commuting by employees. Broadly speaking, these include company vans or buses that take employees to and from work, passes for use on public or private mass transit, employer-provided parking, and qualified bicycle-commuting reimbursements. ${ }^{31}$

\section{A. Bicycle Sharing and Qualified Bicycle-Commuting Reimbursements}

The qualified bicycle-commuting reimbursement benefit was added to the Internal Revenue Code in 2008 as part of the Energy Improvement and Extension Act of 2008. ${ }^{32}$ The Act included a bevy of provisions designed to reduce US reliance on fossil fuels and to encourage conservation, and commuting by bicycle furthers both of those goals. ${ }^{33}$ Accordingly, Congress decided to provide benefits that would encourage people to commute by bicycle, especially since $\$ 132$ already provided benefits that encouraged employer-provided parking and certain other types of commuting expenses. ${ }^{34}$

The qualified bicycle-commuting reimbursement provision allows employers to reimburse employees for reasonable expenses that employees incur to purchase, repair, and store a bicycle. ${ }^{35}$ However, there are significant limitations on these benefits. First, the benefit is available only if the bicycle in question is

30 See 26 USC $\$ 132(a)(5)$, (f). The other specially exempted fringe benefits are noadditional-cost services, qualified employee discounts, working-condition fringes, de minimis fringes, qualified moving-expense reimbursements, qualified retirementplanning services, and qualified military-base realignment and closure fringes. 26 USC $\S 132(\mathrm{a})-(\mathrm{e}),(\mathrm{g}),(\mathrm{m})-(\mathrm{n})(2012)$.

31 For a recent critique of these rules, see generally Subsidizing Congestion: The Multibillion-Dollar Tax Subsidy That's Making Your Commute Worse (Frontier Group and Transit Center Nov 2014), online at http://transitcenter.org/wp-content/uploads/ 2014/11/SubsidizingCongestion-FINAL.pdf (visited Feb 23, 2015).

32 Pub L No 110-343, 122 Stat 3841 (2008), codified at 26 USC $\$ 132$. This law also included the Alternative Minimum Tax Relief Act of 2008 and the Emergency Economic Stabilization Act of 2008, which created the Troubled Asset Relief Program (TARP). Id.

33 See Renewable Energy and Job Creation Act of 2008, HR Rep No 110-658, 110th Cong, 2d Sess 88 (2008); General Explanation of Tax Legislation Enacted in the 110th Congress, 111th Cong, 1st Sess 333 (2009).

3426 USC $\$ 132(f)(1)(\mathrm{A})-(\mathrm{C})(2012)$.

3526 USC $\$ 132(f)(5)(F)(i)$. Expenses to purchase bicycle improvements also are covered. 26 USC $\$ 132(\mathrm{f})(5)(\mathrm{F})(\mathrm{i})$. 
"regularly used" for commuting. ${ }^{36}$ Second, there is a cap on benefits available under the provision..$^{37}$ Each year, an employee can be reimbursed tax-free only for an amount equal to $\$ 20$ multiplied by the number of "qualified bicycle commuting months" in that year-that is, the number of months in which an employee regularly used the bicycle as part of her commute and also did not take advantage of any other qualified transportation fringe benefit offered under $\S 132 .{ }^{38}$ Finally, a reimbursement does not qualify for tax-free treatment if an employee has a choice between the reimbursement and a cash payment. ${ }^{39}$

Considering the statute from the perspective of a regulator, one can understand why these limitations exist. Regulators do not want to just make purchases of particular items tax-free; that would introduce all of the problems described in the bicycle example above.40 As a result, bicycle expenses receive taxfavored treatment only if the bicycle is regularly used for commuting. Both the availability and size of the benefit are tied to the frequency with which the taxpayer uses the bicycle to commute to work.

Nonetheless, the limitations result in a rather narrowly prescribed benefit. The statute was clearly written with the idea that any worker who commutes by bicycle would buy a personal bicycle and use it to commute. There is no benefit available for bicycle commuting that uses the sharing economy. ${ }^{41}$

Last year, the IRS issued Letter 2013-003242 (the "Letter"), which states that employer reimbursements for costs related to bicycle-sharing programs do not constitute qualified bicyclecommuting reimbursements. The IRS's reasoning is based on the text of $\S 132$ : qualified bicycle-commuting reimbursements must be for expenses incurred to purchase, repair, or store a

\footnotetext{
3626 USC $\$ 132(\mathrm{f})(5)(\mathrm{F})(\mathrm{i})$. It is not entirely clear what this means; the most recent regulations governing and clarifying qualified transportation fringes were enacted before the introduction of the qualified bicycle-commuting reimbursement. See Treas Reg $\S 1.132-9$.

3726 USC $\$ 132(\mathrm{f})(5)(\mathrm{F})(\mathrm{ii})(2012)$.

$38 \quad 26$ USC $\$ 132(\mathrm{f})(5)(\mathrm{F})$ (i)-(ii) (2012).

3926 USC $\$ 132(f)(4)(2012)$.

40 See text accompanying notes $16-17$.

41 Commuting with a bicycle rented from a more traditional bicycle-rental company also would not qualify for benefits. The expenses incurred would not be for the "purchase of a bicycle and bicycle improvements, repair, [or] storage" of a bicycle "regularly used" for the employee's commute. 26 USC $\$ 132(\mathrm{f})(5)(\mathrm{F})(\mathrm{i})(2012)$.

42 See generally IRS Office of the Chief Counsel, Letter 2013-0032 (July 26, 2013), online at http://www.irs.gov/pub/irs-wd/13-0032.pdf (visited Feb 23, 2015).
} 
bicycle, and payments made to a bicycle-sharing program do not meet this standard. $4^{3}$

The Letter also states that payments for bicycle-sharing services do not qualify as a transit pass. ${ }^{44}$ Transit passes include tokens, vouchers, and similar items that entitle a person to transportation via a mass-transit facility. 45 The IRS concluded that bicycle-sharing programs are not mass-transit facilities; thus, employer-provided access to a bicycle-sharing program does not qualify as a transit pass.

Prior to the issuance of the Letter, it was not entirely clear that a bicycle-sharing depot is not a mass-transit facility. Neither $\$ 132$ nor the regulations thereunder define what constitutes a mass-transit facility, although the regulations list "train, subway, and bus" systems as examples. ${ }^{46}$ The Letter does not elaborate on how "mass-transit facility" is defined or why bicyclesharing programs are not mass-transit facilities. ${ }^{47}$

Based on the text of the statute, the IRS concluded that bicycle-sharing programs are not eligible for tax-free-fringebenefit status under $\S 132$ as it currently exists, and that changing this result would require action by Congress. ${ }^{48}$ The Letter ends by stating that its author forwarded the taxpayer's suggestion to the Treasury Department's Office of Tax Policy to consider bringing the issue to Congress's attention.

As a matter of legal analysis, the Letter makes perfect sense. As a matter of policy, it does not. Commuting to work on a bicycle that comes from a bicycle-sharing program decreases reliance on fossil fuels and encourages conservation just as much as commuting to work on one's own bicycle. There does not appear to be a policy reason to treat these two situations differently. Yet because the statute is so narrowly tailored, it does not encompass bicycle-sharing programs.

43 See id at *1-2.

44 See id at $* 1$.

4526 USC $\$ 132(\mathrm{f})(5)(\mathrm{A})$.

46 Treas Reg $\S 1.132-9, \mathrm{~A}-16(\mathrm{~b})(2)$

47 Although one could make an argument to the contrary, the IRS's conclusion seems correct to us. Including bicycle-sharing programs in the definition of mass-transit facilities likely would sweep in bicycle- and car-rental companies, which are not typically thought of as mass-transit facilities. Moreover, a definition broad enough to include car rentals could also include long-term car leases from dealerships, which would vastly expand the intended benefit

48 See IRS Office of the Chief Counsel, Letter 2013-0032 at *2 (cited in note 31 ). 
We also question the IRS's conclusion that Congress alone can extend tax-free-fringe-benefit status to bicycle-sharing programs. The text of $\S 132$ expressly authorizes the secretary of the treasury to issue regulations "appropriate to carry out the purposes of this section." ${ }^{49}$ Because treating bicycle-sharing programs as mass-transit facilities would further the purposes of $\S 132$, a regulation that effectuates this result would appear to be within the Treasury Department's power. The Treasury seems unlikely to take this step, however, so changing the tax treatment of bicycle-sharing programs probably will require congressional action.

\section{B. Car Sharing and Qualified Transportation Fringe Benefits}

The vast majority of American commuters get to work by driving in a car, alone. 50 From a policy perspective, car sharing seems like a preferable alternative: if a commuter owns her car and parks it at work, it will often sit idle all day while she works. In the meantime, there must be a place for the commuter to park her car. This encourages less-dense development, which is much harder to serve with mass-transit options. ${ }^{51}$ Car sharing, in contrast, requires less parking capacity, favoring denser development, and car sharing itself works better in more densely populated areas.

Similarly, people who shift away from car ownership and toward car sharing also may have a greater demand for public transportation. For example, suppose that someone could travel to a nearby event either by car or by public transportation. If she already owns a car, the marginal cost of driving to the event is small. Car-sharing services, in contrast, charge based on usage, which raises the marginal cost of traveling to the event by car. This makes public transportation a relatively more attractive option for someone without a car than it is for a person who already owns a car. Greater use of public transportation has direct benefits because traveling by public transportation is more resource efficient than traveling by private car. There are also

\footnotetext{
$4926 \mathrm{USC} \& 132(0)$.

50 See American Association of State Highway and Transportation Officials, Commuting in America 2013: The National Report on Commuting Patterns and Trends ${ }^{*} 5-6$ (Oct 2013), online at http:/traveltrends.transportation.org/Documents/CA10-4.pdf (visited Feb 23, 2015).

51 See Roberta F. Mann, On the Road Again: How Tax Policy Drives Transportation Choice, 24 Va Tax Rev 587, 614-15, 635-38 (2005).
} 
indirect benefits; because public transportation has economies of scale, higher ridership benefits the entire public-transportation system. This can attract new riders, continuing the cycle and producing additional spillover effects.

Finally, studies have found that car sharing reduces total vehicle ownership, as people share cars instead of owning them separately. ${ }^{52}$ This translates to fewer cars being manufactured, which means less oil consumption and greater resource conservation.

Some car-sharing services are unlikely to make sense for commuters. For example, Zipcar, one of the largest car-sharing services in the United States, generally charges users by the hour until they return the shared car to its original location. ${ }^{53}$ This is not likely to be an economical option for someone who drives to work in the morning, stays at the office all day, and then returns home.

However, there are car-sharing services that are more compatible with a commuting model. For example, Car2Go also charges users based on the amount of time that they rent the car, but it allows users to "return" the car to any location within the "home area," which can be quite vast. ${ }^{54}$ In other words, a commuter who lives and works in a metropolitan area with Car2Go could return the car upon arriving at her workplace, meaning that she would pay only for the time required to actually commute. This model might prove economical for some commuters. ${ }^{55}$

52 See, for example, Elliot Martin and Susan Shaheen, The Impact of Carsharing on Household Vehicle Ownership, 38 Access 22, 24 (2011) (finding that car sharing reduced car ownership by an average of 0.47 vehicles per participating household).

53 FAQ: Returning Your Vehicle (Zipcar), online at http://www.zipcar.com/how\#faqscategory-returning-your-vehicle (visited Feb 23, 2015). Enterprise runs a car-sharing rental service that operates on a similar model. See How It Works (Enterprise Car Share), online at http://www.enterprisecarshare.com/about/how-it-works (visited Feb 23, 2015). JustShareIt offers a peer-to-peer rental service, allowing individuals to rent their cars to each other. How It Works (JustShareIt), online at http://www.justshareit.com/jsi/ website/howItWorks.do (visited Feb 23, 2015). This is similarly unsuitable for commuting because it requires bringing the car back to the place where it was picked up.

54 Car2Go, How Does It Work?, online at https://www.car2go.com/en/losangeles/how -does-car2go-work (visited Feb 23, 2015).

55 AutoLib, which allows a user to return a car to any AutoLib rental location-not just the one at which she picked up the car-offers another model that might be economical for some commuters. It is based in France but is soon coming to Indianapolis. See Antony Ingram, French Electric Car-Sharing Service Autolib Coming to ... Indianapolis?!? (Green Car Reports June 11, 2013), online at http:/www.greencarreports.com/ news/1084727_french-electric-car-sharing-service-autolib-coming-to-indianapolis (visited Feb 23, 2015). 
Although $\S 132(\mathrm{f})$ provides tax advantages to encourage taxpayers to commute in more environmentally friendly ways, it does not provide any benefits for car sharing. Even the parking benefits are of no help: the car-sharing services that are potentially compatible with commuting do not require users to pay for parking. ${ }^{56}$

One might also expect that bicycle sharing and car sharing would be more valuable in combination. For example, a commuter might bicycle to work most days, but use car sharing when she has to transport bulky items to or from the office, when the weather is bad, when her back is sore, and so forth. Or a commuter might prefer to drive part of the way to work and bicycle the remainder. But the statute is not structured to permit these sorts of combinations. Qualified bicycle-commuting reimbursements-unlike the other qualified transportation fringe benefits-generally are available only if the commuter does not take advantage of other qualified transportation fringe benefits. ${ }^{57}$ Encouraging these hybrid commutes would require a significant change to the statute.

\section{REGULATORY RESPONSES}

Unfortunately, identifying the problems between existing regulations and new industries is easier than solving those problems. A full discussion of possible responses is beyond the scope of this Essay, but we briefly note two diametrically opposite strategies that advocates tend to propone. Both are imperfect.

One approach (the "Proactive Approach") is to change existing regulations to encourage the growth of new industries. In the context of $\S 132$, this would mean expanding the statute to accord benefits to some or all of the transportation-sharing mechanisms discussed above. The advantage of the Proactive Approach is that it enables the use of regulations to encourage activities that are deemed beneficial. However, this approach is difficult to implement on a prospective basis. As described previously, when new business models are still in flux, it is hard to craft regulatory rules that target the activity in question. This means following one of two paths: The first is to create narrow

56 Car2Go, for example, generally covers parking costs. Parking FAQs (Car2Go), online at https://www.car2go.com/common/data/locations/usa/los_angeles/Los_Angeles _Parking_FAQ.pdf. Because AutoLib cars are dropped off at their own rental locations, commuters face no parking costs.

57 See 26 USC $\$ 132(f)(5)$ (F)(iii)(II). 
regulations after business models resolve themselves, in which case regulations will consistently lag behind the market and therefore hamper innovation. The alternative is to write favorable regulations broadly, in which case they will bestow benefits on activities that were not intended to receive them. This tactic also tends to create loopholes that undermine the regulatory structure.

The second proposed approach (the "Neutrality Approach") is to cut back on regulatory benefits all around. The idea is to place new business models on an even footing by limiting the advantages accorded to existing business models. This tends to produce simpler regulatory structures, which has several advantages. The problem with the Neutrality Approach is that it entails abandoning the use of regulatory policy to encourage or discourage certain transactions. This can be a high price to pay if some transactions create more externalities than others. The Neutrality Approach is also not as easy to carry out as it may initially sound. For example, in the context of $\S 132$, leveling the playing field might require treating employees as receiving taxable income equal to the value of the free parking that employers provide. This may pose difficult valuation problems. And what about employees who do not use the free parking but have the option to do so-how much is that option worth? The administrative costs of resolving these questions accurately may far outstrip the benefits. Finally, we note that the overall trend toward greater regulation in many areas may make this approach increasingly impractical.

\section{CONCLUSION}

This Essay has used the sharing economy and the tax-free transportation-fringe-benefit rules to illustrate the challenges that existing laws and regulations can pose for new industries. It has also identified two of the chief approaches that policymakers use to address these challenges.

In the specific context of the tax-free transportation-fringebenefit rules, policymakers currently seem focused on the Proactive Approach. ${ }^{58}$ In tax law and policy more generally, the

58 Legislators have introduced several bills that would extend tax-free-fringebenefit status to bicycle-sharing programs. See Katie Honan, Legislation Would Let You Pay for Bike Commute with Pre-tax Cash (DNAinfo July 22, 2014), online at http://www.dnainfo.com/new-york/20140722/jackson-heights/legislation-would-let-youpay-for-bike-commute-with-pre-tax-cash (visited Feb 23, 2015); Nathan Hurst, Bike 
Proactive and Neutrality Approaches often interact cyclically. Congress enacts special rules to encourage certain actions and discourage others. These provisions erode the tax base and add complexity until a tipping point is reached and Congress enacts a base-broadening reform that eliminates many benefits. Then support builds for encouraging some worthy practice, or discouraging a harmful one, and Congress enacts a new special rule, restarting the cycle.

This cycle will continue-until someone comes up with a better innovation.

Sharing Is a Winner in the Senate Tax Bill (Roll Call Apr 7, 2014), online at http://www.rollcall.com/news/bicycle_sharing_is_a_winner_in_the_senate_tax_bill231975-1.html (visited Feb 23, 2015); Angie Schmitt, Blumenauer Introduces a Tax Break for Bike-Share Commuters (StreetsBlog Network Nov 14, 2013), online at http://streetsblog.net/2013/11/14/blumenauer-introduces-a-tax-break-for-bike-sharecommuters (visited Feb 23, 2015). 